\title{
Accumulation of Lead and Arsenic by Lettuce Grown on Lead-arsenate Contaminated Orchard Soils
}

\author{
E. E. Codling* \\ USDA-ARS, Environmental Management and Byproduct Utilization Laboratory, 10300 Baltimore Avenue Beltsville, \\ MD. 20705
}

\begin{abstract}
Lead-arsenate was used to control codling moth (Cydia pomonella) in apple (Malus sylvestris Mill) orchards from the 1900's to the1960's. Lead and arsenic are generally immobile and remain in the surface soil. Some orchard lands are being used for vegetable crop production. There are concerns of lead and arsenic accumulation in vegetables crops grown in these soils. Objectives were to 1) determine lead and arsenic uptake by lettuce and 2) determine the translocation into lettuce leaves. Lettuce (Lactuca sativa $\mathrm{L}$ ) was grown for 60 days in four orchard soils (Bagstown, Hudson, Spike and Cashmont) with total lead and arsenic ranging from 350-961 and 93-291 mg kg ${ }^{-1}$ respectively. Plants were harvested and separated in younger and older leaves, rinsed and dried. Yield reduced to 18, 11, 38 and 31 percent for plants grown on Bagstown, Hudson, Spike and Cashmont soils respectively. Tissue lead and arsenic concentrations were higher in the plants grown on the lead-arsenate soils compared to control. Lead and arsenic concentrations ranged from 0.44 to 3.91 and 4.65 to $24.1 \mathrm{mg} \mathrm{kg}^{-1}$ respectively. Unlike arsenic levels in water, there are no established standard for arsenic in food; therefore, it is difficult to determine if arsenic levels observed in this study should be of concern to the consumer. Until there are established standard limits for arsenic in food, care should be taken when these soils are used for lettuce production without soil remediation. Further studies are needed to determine what fraction of lead and arsenic in lettuce is bioaccessible when consumed.
\end{abstract}

Keywords: Pesticide, vegetables.

\section{INTRODUCTION}

Lead arsenate was used as a foliar spray from the 1900s to the1960's to control codling moth (Cydia pomonella) in apple (Malus sylvestris Mill) orchards [1,2]. Lead $(\mathrm{Pb})$ and arsenic (As) are generally immobile in soil and remain in the surface soil due to adsorption by fine silt and clay particles, amorphous oxides, and organic matter [3-6]. Concentrations of $\mathrm{Pb}$ and $\mathrm{As}$ in some orchard soils exceeded 900 and 200 $\mathrm{mg} \mathrm{kg}^{-1}$ respectively, [7, 8]. These concentrations are much higher than the 400 and $40 \mathrm{mg} \mathrm{kg}^{-1}$ considered safe by EPA for $\mathrm{Pb}$ and $\mathrm{As}$ in contaminated soils [9].

\section{Lead}

Lead is a toxic element that occurs naturally in rocks, soil, plants, water, and the atmosphere. Lead has been used in many products such as in anti-knock compound, gasoline, pesticides, paints, and storage batteries [2]. It can be harmful to humans when inhaled, ingested directly through the consumption of contaminated water, or ingested indirectly by consuming crops grown on contaminated soils or irrigated with contaminated water $[10,11]$. Diseases such as neurobe havioral impairment, hypertension, and cardiovascular

*Address correspondence to this author at the USDA-ARS, Environmental Management and Byproduct Utilization Laboratory, 10300 Baltimore Avenue Beltsville, MD. 20705; Tel: 301-504-5708; Fax: 301-504-5456;

E-mail: eton.codling@ars.usda.gov disease in humans are attributed to excessive $\mathrm{Pb}$ exposure, especially in growing children [11].

\section{Lead in Plants}

Plants generally do not accumulate substantial amounts of $\mathrm{Pb}$ in tops or edible tissues [12]. Lead is mostly available for plant uptake in soils with low organic matter, low $\mathrm{pH}$, and low phosphate [13]. When phosphate is present in the rhizosphere, an insoluble $\mathrm{Pb}$ compound (chloropyromorphite) is formed near or in the plant roots [14]. Brown et al. (2004) [15] reported a reduction in soluble $\mathrm{Pb}$ with increased concentration of phosphate. Nriagu (1978) [16] suggested that $\mathrm{Pb}$ in soils with high $\mathrm{pH}$ and phosphate will precipitate as $\mathrm{Pb}$ phosphate, $\mathrm{Pb}$ carbonate, or $\mathrm{Pb}$ hydroxides that are not readily available for plant uptake.

Studies have shown that some vegetable crops remove $\mathrm{Pb}$ from $\mathrm{Pb}$ contaminated soils. Chisholm (1972) [17] reported that $\mathrm{Pb}$ concentration in carrots grown on two lead-arsenate contaminated soils exceeded the Canadian residue tolerance levels for human safety of $2 \mathrm{mg} \mathrm{kg}^{-1}$. Boon and Soltanpour (1992) [18] found that $\mathrm{Pb}$ concentration of leafy vegetables such as spinach ranged from $<5$ to $45 \mathrm{mg} \mathrm{kg}^{-1}$ when grown on soils with a total $\mathrm{Pb}$ concentration above $2000 \mathrm{mg} \mathrm{kg}^{-1}$. Creger and Peryea (1994)[19] concluded that the increased $\mathrm{Pb}$ concentration of leafy vegetable crops grown on a $\mathrm{Pb}$ contaminated soil may have resulted from soil particles containing $\mathrm{Pb}$ adhering to the plant surface. 


\section{Arsenic}

Arsenic is a ubiquitous element that is found naturally in the environment [20]. Inorganic arsenite $\left(\mathrm{As}^{3+}\right)$ and arsenate $\left(\mathrm{As}^{5+}\right.$ ) are the dominant toxic As species found in food and drinking water [21-23]. High exposure to As has been shown to cause skin, lung and bladder cancer in humans [24-26]. Humans can be exposed to As directly through the consumption of water and indirectly by consuming crops grown on As contaminated soils or irrigated with contaminated water [22, 23, 27-29]. It has been estimated that 35 to 77 million people in Bangladesh are at risk of As poisoning from drinking As contaminated well water [28]. The major pathway for human As contamination is the consumption of drinking water [28, 30]. The recommended guideline set by Environmental Protection Agency (EPA) for As in drinking water is $10 \mu \mathrm{gL}^{-1}$ [9], but it currently has no recommended guidelines for As in food crops.

\section{Arsenic in Plants}

Arsenic is not essential for plant growth and inorganic As species are generally regarded as potentially phytotoxic when they accumulate in soils $[23,31]$. Uptake, accumulation, and translocation of As by plants are influenced by factors such as 1) soil properties, 2) soil As concentration, 3) presence of other ions which compete with As for sorption on soil surfaces, and 4) plant species and age [23, 32, 33]. Geng et al. (2006) [34] stated that soil-plant transfer of As is one pathway for human exposure to As. It is believed that most food crops are injured by soil As before the crops can accumulate enough As to become a health risk to humans and animals [35, 36]. For example, Gusman et al., (2013) [21] observed yield reduction in lettuce grown hydroponically. There are concerns that $\mathrm{Pb}$ and As will enter the food chain through the consumption of vegetables crops grown on lead-arsenate contaminated soils. Therefore, the objectives of this study were to 1) determine $\mathrm{Pb}$ and As uptake by lettuce 2) determine movement of $\mathrm{Pb}$ and $\mathrm{As}$ in lettuce leaf tissue.

\section{MATERIALS AND METHODS}

\section{Soil Collection}

Bagstown loam (Oxyaquic Hapludults), Spike sandy loam (Psammentic Haplaquolls), Hudson silty clay loam (Glossaquic Hapludalf), and Cashmont silt loam (Aridic Haploxerolls) were collected from the surface $15 \mathrm{~cm}$ depth from four orchards in Maryland, Michigan, New York and Washington State with histories of lead-arsenate use. A nonorchard soil, Christiana (control) fine sandy loam (Typic Paleudult), was collected from Maryland for use as a control soil.

\section{Soil Analysis before pH Adjustment}

Soil $\mathrm{pH}$ was measured in a 1:1 soil to water slurry using a combined electrode; electrical conductivity (EC) measured in a 1:2 soil to water slurry using a Orion conductivity meter and organic carbon was determined with a LECO-CN analyzer (St Joseph, MI). Soil texture was determined by the pipette method [37]. Total soil $\mathrm{Pb}$ and As were determined using the aqua regia digestion method [38]. Soil $\mathrm{Pb}$ concentrations in the digested solution were determined using a
Perkin Elmer inductively coupled plasma-optical emission spectrometer (ICP-OES) with scandium as an internal standard. Soil As concentrations in solution were determined by an ICP-OES hydride method outlined by Anderson and Isaacs (1995) [39]. The procedure was as follows: $4 \mathrm{ml}$ of soil extract solution was placed into $15 \mathrm{~mL}$ test tubes and 1.5 $\mathrm{mL}$ concentrated $\mathrm{HCl}$ (trace element grade), $2 \mathrm{~mL}$ potassium iodide solution, and $2.5 \mathrm{~mL} 1.73 \mathrm{M}$ sulfamic acid were mixed and allowed to stand for 30 minutes for reaction to occur. A $0.5 \%$ sodium borohydride and $0.05 \%$ sodium hydroxide solution was used to generate arsine gas as it entered the nebulizer of the ICP-OES.

\section{Soil Analysis after pH Adjustment}

In order to attain a $\mathrm{pH}$ of 6.5 calcium and magnesium carbonate were mixed with the soil and allowed to incubate for two weeks. After two weeks, $\mathrm{pH}$ and $\mathrm{EC}$ were determined as outlined above. The Mehlich-3 (M-3) method [40] was used to determine extractable soil $\mathrm{Pb}$ and $\mathrm{As}$. Lead and As concentrations in the extracting solution were analyzed using ICP-OES as outlined above.

\section{Experiment}

This growth chamber pot study was conducted at the United States Department of Agriculture; Agricultural Research Service in Beltsville Maryland, USA. The $\mathrm{pH}$ adjusted soils were fertilized with $300 \mathrm{~kg} \mathrm{ha}^{-1}$ of $\mathrm{P}$ as calcium phosphate $\mathrm{Ca}\left(\mathrm{H}_{2} \mathrm{PO}_{4}\right)_{2}$ and potassium phosphate $\left(\mathrm{KH}_{2} \mathrm{PO}_{4}\right)$, $100 \mathrm{~kg} \mathrm{ha}^{-1}$ nitrogen as ammonium nitrate $\left(\mathrm{NH}_{4} \mathrm{NO}_{3}\right), 60 \mathrm{~kg}$ $\mathrm{ha}^{-1} \mathrm{Mg}$ as magnesium sulfate $\left(\mathrm{MgSO}_{4}\right)$ and magnesium carbonate $\left(\mathrm{MgCO}_{3}\right)$ and $232 \mathrm{~kg} \mathrm{ha}^{-1} \mathrm{~K}$ as $\left(\mathrm{KH}_{2} \mathrm{PO}_{4}\right)$. Soil and fertilizers were mixed and incubated moist (near field capacity) for four weeks. Fertilizer rates used were based on the fertilizer recommendation for lettuce production.

There were five soils $\mathrm{x}$ four replications for each soil. Four kilograms of each soil (based on air dried weight) were placed in $20 \times 18 \mathrm{~cm}$ plastic pots and planted with Parris Island romaine lettuce (Lactuca sativa L.). Soil surfaces of each pot were covered with $2 \mathrm{~cm}$ of plastic beads to reduce splashing during watering. Pots were placed into a plastic saucer, and then placed in a growth chamber in a randomized complete block design with $16 \mathrm{hr}$ light at $25^{\circ} \mathrm{C}$ and $8 \mathrm{hr}$ dark at $19^{\circ} \mathrm{C}$. Plants were watered every two days or as needed to maintain field capacity. Any leachate collected was returned to the pots. Eight days, after germination, plants were thinned to 2 plants per pot and grown for 60 days. Lettuce was harvested by cutting the stem above the fourth lowest leaves. The harvested leaves were separated into newer and older leaves, washed with sodium lauryl sulfate and rinsed with deionized water and freeze-dried for 3 days for yield determination. After yield was determined, plant tissue was ground using a Whaley mill, mixed-well, and stored until analysis.

At end of the experiment, soil in each pot was mixed and a sample was collected for $\mathrm{pH}, \mathrm{EC}$ and $\mathrm{M}-3$ extractable $\mathrm{Pb}$ and As determination.

\section{Plant Analysis}

A microwave digestion method as outlined by Codling and Ritchie (2005) [7] was used for plant sample digestion. 
Table 1. Texture, pH, organic carbon (OC), electrical conductivity (EC), total and Mehlich-3 (M-3) extractable Pb and As in soil used in experiment before and after $\mathrm{pH}$ adjustment.

\begin{tabular}{|c|c|c|c|c|c|c|c|c|c|c|}
\hline Soils & Texture & $\mathbf{O C}$ & $\mathbf{p H}$ & $\mathbf{p H}$ & $\mathbf{E C}$ & $\mathbf{E C}$ & Total Pb & M-3 Pb & Total As & $\mathbf{M - 3}$ As \\
\hline & Before & Before & Before & After & Before & After & Before & After & Before & After \\
\hline \hline Control & Sandy loam & 18.0 & 5.32 & 6.29 & 0.48 & 1.00 & 20 & $<0.01$ & 4.0 & 0.45 \\
\hline Bagstown & Sandy loam & 100 & 5.16 & 6.69 & 0.80 & 1.19 & 676 & 263 & 133 & 20.29 \\
\hline Hudson & Silt loam & 43.9 & 4.49 & 6.12 & 1.05 & 1.24 & 435 & 164 & 153 & 13.15 \\
\hline Spike & Sandy loam & 14.4 & 7.08 & 6.07 & 0.35 & 0.62 & 350 & 252 & 93 & 37.75 \\
\hline Cashmont & Silt loam & 12.4 & 5.26 & 6.32 & 0.20 & 0.55 & 961 & 524 & 291 & 110 \\
\hline
\end{tabular}

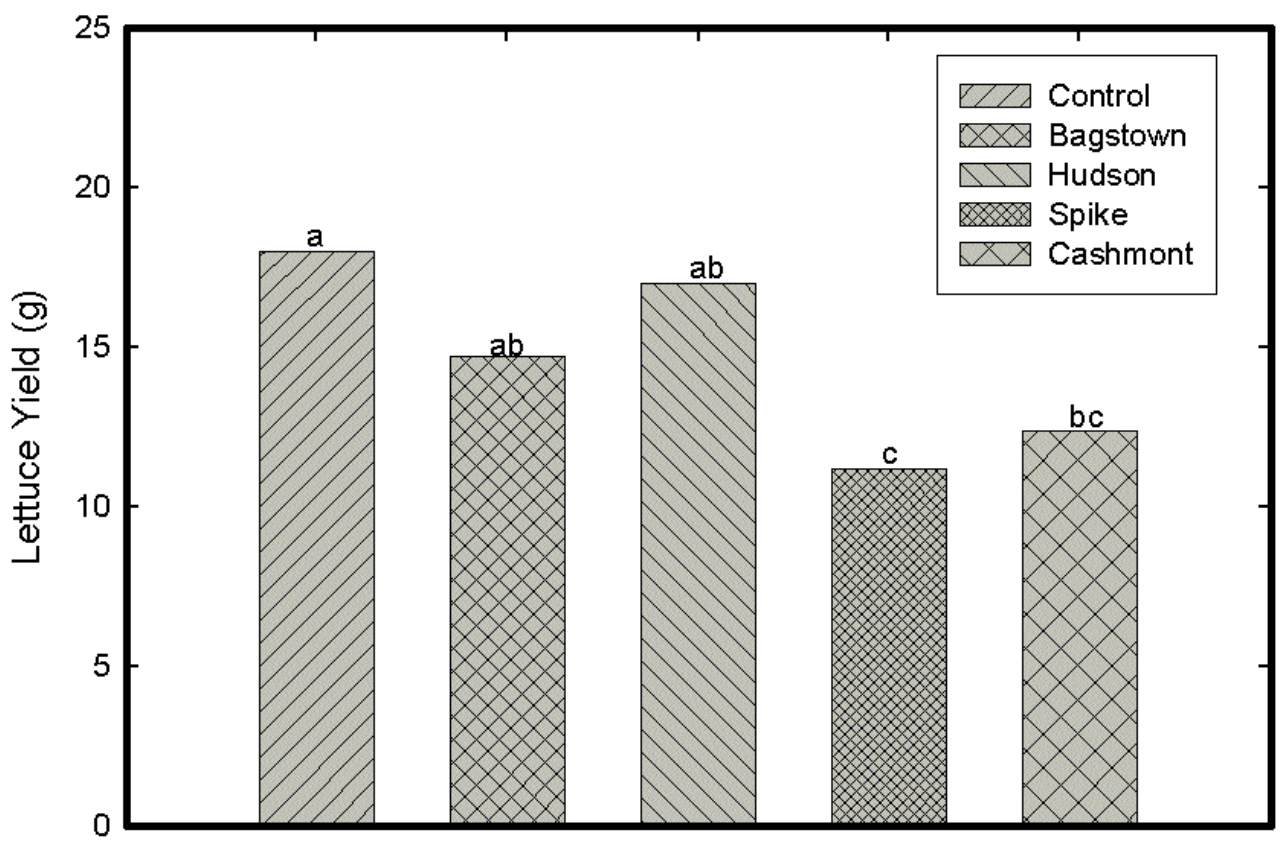

Soils

Fig. (1). Yield of lettuce grown on a control soil and four lead-arsenate contaminated orchard soils. Columns with similar letters are not significant at $\mathrm{p}<0.05$.

$\mathrm{Pb}$ in the digested solution was determined using ICP-OES as outlined above. Plant As concentration was determined using the hydride procedure previously outlined above. To ensure accuracy and precision, all samples were analyzed in duplicate with one blank for every ten samples. Peach leaves from the National Institute of Standards (NIST), Gaithersburg MD, was included as standard after every 30 samples.

Statistical analysis of the data was carried out using SAS Proc Mixed to model the treatment effects. Means comparisons were done with Sidak adjusted p-values so that the experiment-wise error was 0.05 [41].

\section{RESULTS AND DISCUSSION}

Selected properties of soils used in the experiment are presented in (Table 1). Adjusting the soil $\mathrm{pH}$ before the ex- periment influenced the $\mathrm{pH}$ and EC values. M-3 extractable As concentrations in the contaminated orchard soils were much lower than those of the total concentrations. Total $\mathrm{Pb}$ concentration in three of the four orchard soils exceeded the $400 \mathrm{mg} \mathrm{kg}^{-1}$ level considered hazardous to exposed organisms [42], and could pose health risk if these soils are used for crop production without remediation. Total As concentration in these orchard soils exceeded the $40 \mathrm{mg} \mathrm{kg}^{-1}$ limit USEPA has set for As contaminated soil [9].

\section{Lettuce Yield}

Lettuce grown on lead-arsenate soils yielded lower than those grown on the control soil (Fig. 1). The difference, however, was only significant for the plants grown on the Spike and Cashmont soils. For example, yields were 38 and 31 percent lower for the Spike and Cashmont soils respectively compared to the control soil. Plants grown on the 
Table 2. Lead (Pb) and arsenic (As) concentrations in lettuce leaves grownon lead-arsenate contaminated orchard and control soils.

\begin{tabular}{|c|c|c|c|}
\hline Soils & Plant & Pb & As \\
\hline & Leaves & BDL† & $0.05 \mathrm{f}$ \\
\hline Control & New & BDL & $0.48 \mathrm{f}$ \\
\hline Control & Old & $0.27 \mathrm{c}$ & $3.15 \mathrm{ef}$ \\
\hline Bagtown & New & $0.61 \mathrm{c}$ & $19.05 \mathrm{c}$ \\
\hline Bagtown & Old & $0.38 \mathrm{c}$ & $2.00 \mathrm{f}$ \\
\hline Hudson & New & $0.66 \mathrm{c}$ & $7.30 \mathrm{de}$ \\
\hline Hudson & Old & $0.50 \mathrm{c}$ & $7.42 \mathrm{de}$ \\
\hline Spike & New & $1.97 \mathrm{~b}$ & $24.04 \mathrm{~b}$ \\
\hline Spike & Old & $2.11 \mathrm{~b}$ & $9.67 \mathrm{~d}$ \\
\hline Cashmont & New & $5.81 \mathrm{a}$ & $41.44 \mathrm{a}$ \\
\hline Cashmont & Old & & \\
\hline
\end{tabular}

$\uparrow \mathrm{BDL}=$ below detection limit.

Hudson soil had the highest yield of plants grown on the lead-arsenate contaminated soils. This soil had the lowest M3 extractable $\mathrm{Pb}$ and $\mathrm{As}$ of the four soils (Table 1). Yield reduction in lettuce was also observed by Michalska and Asp (2001) [43] when grown $0.5 \mu \mathrm{M} \mathrm{Pb}$ solution. Reduction in lettuce yield in plants grown in an As rich environment may result from interference of As in the photochemical and biochemical steps of photosynthesis [21].

\section{Lettuce Tissue $\mathrm{Pb}$ and As Concentrations}

Lead concentration in the control soil was below the instrument detection limits of $0.03 \mathrm{mg} \mathrm{kg}^{-1}$. Lead and As concentration were highly influenced by soil, leaf age and interaction soil $\mathrm{x}$ leaf age $(\mathrm{p}<0.0001)$. In all cases, $\mathrm{Pb}$ concentrations were higher in plants grown on the lead-arsenate soils compared to the control soil (Table 2). Lead concentrations were higher in the older leaves compared to the younger leaves. For example, $\mathrm{Pb}$ concentrations were 56, 42, 75 and 64 percent higher in the older leaves compared to the younger leaves for the plants grown on Bagstown, Hudson, and Spike and Cashmont soils, respectively.

Arsenic concentrations were higher in the plants grown on the lead-arsenate contaminated soil compared to the control (Table 2). Arsenic concentrations in the older leaves were higher than in the younger leaves. For example, As concentrations were 84, 73, 69 and 77 percent higher in the older leaves compared to the younger leaves for plants grown on the Bagstown, Hudson, Spike and Cashmont soil respectively.

The higher $\mathrm{Pb}$ and $\mathrm{As}$ concentrations observed in the older leaves demonstrated that $\mathrm{Pb}$ and $\mathrm{As}$ are not readily translocated from older to younger leaves. The higher $\mathrm{Pb}$ and As concentrations observed in the older leaves is not a result of soil contamination from splashing during watering as concluded by Greger and Peryea (1994) [19], because in this study the soil surface of each pot was covered with plastic beads and the four lower leaves were not harvested.
Averaged over leaf age, $\mathrm{Pb}$ concentrations were higher in the plants grown on the Cashmont and Spike soil compared to Bagstown and Hudson (Table 3). There was no significant difference in lettuce $\mathrm{Pb}$ concentrations between the plants grown on Bagstown and Hudson soils. Even though, the total $\mathrm{Pb}$ concentrations in the Bagstown and Hudson were higher than in the Spike soil, tissue $\mathrm{Pb}$ concentrations in the plants grown in the Bagstown and Hudson were significantly lower than the plants grown on the Spike soil (Table 3). The lower tissue $\mathrm{Pb}$ concentrations observed in the plants grown on the Bagstown and Hudson soils may have resulted from low extractable $\mathrm{Pb}$ in Bagstown and Hudson soils. Brown et al. (2001) [15] stated that change in soil Pb mineralogy through the application of soil amendment such as phosphate fertilizer can reduce the extractability and plant availability of $\mathrm{Pb}$. The lettuce $\mathrm{Pb}$ concentrations observed in this study were much lower than the $37-87 \mathrm{mg} \mathrm{kg}^{-1}$ that was found by Bunzl et al. (2001) [44] when lettuce was grown in Black and Red slags with $\mathrm{Pb}$ concentrations ranging from 1580-5460 $\mathrm{mg} \mathrm{kg}^{-1}$.

Table 3. Lead (Pb) and arsenic (As) concentrations in lettuce grown on lead-arsenate contaminated orchard and control soils, averaged over leaf age.

\begin{tabular}{|c|c|c|}
\hline Soils & Pb & As \\
\hline & $-\cdots-----\mathbf{m g ~ k g}^{-1}-\cdots$ \\
\hline \hline Control & $<0.03 \mathrm{c} \dagger$ & $0.26 \mathrm{e}$ \\
\hline Bagtown & $0.44 \mathrm{c}$ & $11.57 \mathrm{c}$ \\
\hline Hudson & $0.52 \mathrm{c}$ & $4.65 \mathrm{~d}$ \\
\hline Spike & $1.24 \mathrm{~b}$ & $15.24 \mathrm{~b}$ \\
\hline Cashmont & $3.91 \mathrm{a}$ & $24.11 \mathrm{a}$ \\
\hline
\end{tabular}

$\dagger$ Means within a column having letters in common is not significantly different at $\mathrm{p}<$ 0.05 . 
Table 4. Soil pH, electrical conductivity (EC), Mehlich-3 extractable Pb and As in lead-arsenate contaminated and control soils after lettuce crop.

\begin{tabular}{|c|c|c|c|c|}
\hline Soils & pH & EC & Pb & As \\
\hline \multicolumn{2}{|c|}{$\mathbf{m S a} / \mathbf{c m}$} & & $1.64 \mathrm{e}$ & $0.32 \mathrm{~d}$ \\
\hline \hline Control & $6.08 \mathrm{~b} \dagger$ & $0.69 \mathrm{a}$ & $271 \mathrm{~b}$ & $30.90 \mathrm{~b}$ \\
\hline Bagstown & $6.09 \mathrm{ab}$ & $0.36 \mathrm{~b}$ & $146 \mathrm{~d}$ & $15.20 \mathrm{c}$ \\
\hline Hudson & $6.01 \mathrm{~b}$ & $0.37 \mathrm{~b}$ & $222 \mathrm{c}$ & $40.10 \mathrm{~b}$ \\
\hline Spike & $6.49 \mathrm{a}$ & $0.30 \mathrm{~b}$ & $461 \mathrm{a}$ & $117 \mathrm{a}$ \\
\hline Cashmont & $6.27 \mathrm{ab}$ & $0.46 \mathrm{~b}$ & \\
\hline
\end{tabular}

$\dagger$ Means within a column having letters in common is not significantly different at $\mathrm{p}<0.05$.

Arsenic concentrations increased significantly in lettuce grown in the lead-arsenate soils (Table 3). Among the leadarsenate contaminated soils, As concentrations were highest in the plants grown Cashmont soil and lowest in those grown in the Hudson soil which reflects the M-3 extractable As (Tables 1 and 4). Arsenic concentrations in the plants grown on the Cashmont soil were 52, 81 and 37 percent higher than plants grown on the Bagstown, Hudson and Spike soils, respectively.

\section{Selective Properties of Soil after Experiment}

Soil $\mathrm{pH}$ values between the control and the lead-arsenate contaminated soils were less than one $\mathrm{pH}$ unit. EC value was higher in the control soil compared to the lead-arsenate soils (Table 4). Mehlich-3 extractable $\mathrm{Pb}$ concentrations were higher in the lead-arsenate contaminated soils compared to the control. Lead concentrations were highest in the Cashmont soil and lowest in the Hudson soil (Table 4). M-3 extractable $\mathrm{Pb}$ concentrations in the Hudson, Spike and Cashmont soils were 18,30 and $63 \mathrm{mg} \mathrm{kg}^{-1}$ lower than before the experiment (Tables 1 and 4). The reduction in $\mathrm{Pb}$ may have resulted from the addition of $\mathrm{P}$ fertilizer to these soils. It has been demonstrated by $[8,15,45]$ that phosphorus addition to $\mathrm{Pb}$ contaminated soils will reduce $\mathrm{Pb}$ solubility.

M-3 extractable As concentrations were higher in the lead-arsenate contaminated soils than the control. Arsenic concentrations were $10,2,2$ and $7 \mathrm{mg} \mathrm{kg}^{-1}$ higher after the experiment for the Bagstown, Hudson, Spike and Cashmont soils, respectively. The higher extractable As after the experiment may have resulted from the addition $\mathrm{P}$ fertilizer. Codling (2007) [45] and Peryea (1998) [8] reported that adding $\mathrm{P}$ to lead-arsenate contaminated soil will increase As solubility because phosphate and arsenate exhibit similar physicochemical behaviors in soils and phosphate absorb more readily than arsenate on soil and organic matter surfaces.

\section{CONCLUSION}

Lettuce yield was reduced when grown on lead-arsenate contaminated soils. From this study lettuce plants did accumulate $\mathrm{Pb}$ and $\mathrm{As}$, but mostly in the older leaves. Unlike As levels in water, there are no established standard for As in food; therefore, it is difficult to determine if the As levels observed in this study should be of concern to the consumer.
Until there are established standards limits for As in food, care should be taken when these soils are used for lettuce production without soil remediation. Further studies are also needed to determine what fraction of the $\mathrm{Pb}$ and $\mathrm{As}$ in the lettuce is bioaccessible when consumed by human and animals.

\section{CONFLICT OF INTEREST}

The authors confirm that this article content has no conflict of interest.

\section{ACKNOWLEDGEMENTS}

The authors sincerely acknowledge Drs. Darryl Warncke, Wendell Norvell, Frank Peryea and Rufus Chaney for providing the orchard soils and Ms. Mebret Gesese for her technical assistance in conducting the study.

Mention of brand name or trademark does not constitute endorsement of the product by USDA and does not imply its approval to the exclusion of other products that may also be suitable.

\section{REFERENCES}

[1] Merry RH, Tiller KG, Alston AM. Accumulation of copper, lead and arsenic in some australian orchard soils. Australian J Soil Res 1983; 21: 549-61.

[2] Peryea FJ. Historical use of lead arsenated insecticides, resulting soil contamination and implications for soil remediation. p. 1-8 Proc. $16^{\text {th }}$ World Congress of Soil Science, Montpellier, France 1998a; pp. 20-6.

[3] Merwin I, Pruyne LPT, Ebel Jr. JG, Manzell KL, Lisk DA. Persistence, phytotoxicity, and management of arsenic, lead and mercury residues in old orchard soils of new york state. Chemosphere 1994; 29: 1361-7.

[4] Peryea FJ. Phosphate-induced release of arsenic from soils contaminated with lead arsenate. Soil Sci Soci Am J 1991; 55: 1301-6.

[5] Renshaw CE, Bostick BC, Feng X, et al. Impact of land disturbance on the fate of arsenical pesticides. J Environ Qual 2006; 35: 61-7.

[6] Sharma RK, Agrawal M, Marshall F. Heavy metal contamination of soil and vegetables in suburban areas of varanasi, india. Ecotoxicol Environ Safety 2007; 66: 258-66.

[7] Codling EE, Ritchie JC. Eastern gamagrass uptake of lead and arsenic from lead arsenate contaminated soil amended with lime and phosphorus. Soil Sci 2005; 170: 413-24.

[8] Peryea FJ. Phosphate starter fertilizer temporarily enhances soil arsenic uptake by apple trees grown under field conditions. HortScience 1998b; 33: 826-9. 
[9] U.S. Environmental Protection Agency (EPA). Integrated Risk Information System for Inorganic Arsenic. U.S. Environmental Protection Agency. Carcinogenesis Assessment last revised 2013. Available from: http://www.epa.gov/iris/subst/0278.htm. [Accessed March 5, 2014].

[10] Andra SS, Sarkar D, Datta R, Saminathan S. Lead in soils in paint contaminated residential sites at San Antonio, Texas, and Baltimore, Maryland. Bull Environ Contaminat and Toxicol 2006; 77: 643-50.

[11] Fewtrell LJ, Pruss-Ustun A, Landrigan P, Ayuso-Mateos JL. Estimating the global burden of disease of mild mental retardation and cardiovascular diseases from environmental lead exposure. Environ Res 2004; 94: 120-33.

[12] Chaney RL, Ryan JA. Risk based standards for arsenic, lead and cadmium in urban soils : Summary of information and methods developed to estimate standards for $\mathrm{cd}, \mathrm{pb}$ and as in urban soils. Proc. DECHEMA, Frankfurt1994.

[13] Zandstra BH, De Kryger TA. Arsenic and lead residues in carrots from foliar applications of monosodium methanearsonate (msma): a comparison between mineral and organic soils, or from soil residues. Food Addit Contamin 2007; 24: 34-42.

[14] Cotter-Howells JD, Champness PE, Charnock JM. Mineralogy of pb-p grains in the roots of agrostis capillaris 1 . By atem and exafs. Mineralog Mag 1999; 63: 777-89.

[15] Brown S, Chaney R, Hallfrisch J, Ryan JA, Berti WR. In situ soil treatments to reduce the phyto- and bioavailability of lead, zinc, and cadmium. J Environ Qual 2004; 33:522-31.

[16] Nriagu JO. Lead in soils and sediments and major soil types., In J. O. Nriagu, (ed.) The biogeochemistry of lead in the environment. ed. Elsevier/North-Holland Biomedical Press; New York, NY, 1978, pp. 15-72.

[17] Chisholm D. Lead, arsenic, and copper content of crops grown on lead arsenate-treated and untreated soils. Can J Plant Sci 1972; 52 : 583-8.

[18] Boon DY, Soltanpour PN. Lead, cadmium, and zinc contamination of aspen garden soils and vegetation. J Environ Qual 1992; 21: 826.

[19] Creger TL, Peryea FJ. Phosphate fertilizer enhances arsenic uptake by apricot liners grown in lead-arsenate-enriched soil. HortScience 1994; 29: 88-92.

[20] Nebergall WH, Schmidt FC, Holtzclaw HF. Arsenic. General Chemintry $5^{\text {th }}$ edition, Bailar JC (ed). D.C Heat and Compony 1996; pp 924

[21] Gusman G S, Oliveira J A, Farnese FS, Cambraia J. Arsenate and arsenite: the toxic effects on photpsynthesis and growth of lettuce plants. Acta Physiol Plant 2013; 35: 1201-9.

[22] Diaz OP, Leyton I, Muñoz O, et al. Contribution of water, bread, and vegetables (raw and cooked) to dietary intake of inorganic arsenic in a rural village of northern chile. J Agri Food Chem 2004; 52: 1773-9.

[23] Chaturvedi I. Effects of arsenic concentrations and forms on growth and arsenic uptake and accumulation by indian mustard (Brassica junceal L.) genotypes. J Central Europ Agri 2006; 7: 3140.

[24] Anawar H M, Garcia-Sanchez A, Hossain MN, Akter S. Evaluation of health risk and arsenic levels in vegetables sold in markets of Dhaka (Bangladish) and Salamanca (Spain) by hydrice Generation Atomic Absorption Spectroscopy. Bull Environ Contam Toxicol 2012; 89: 620-5

[25] Jones FT. A broad view of arsenic. Poultry Sci 2007; 86: 2-14.
[26] Ng JC, Wang J, Shraim A. A global health problem caused by arsenic from natural sources. Chemosphere 2003; 52: 1353-9.

[27] Chen CJ, C.W. Chen CW, Wu MM, Kuo TL. Cancer potential in liver, lung, bladder and kidney due to ingested inorganic arsenic in drinking water. British J Cancer 1992; 66: 888-92.

[28] Smith AH, Lingas EO, Rahman M. Contamination of drinkingwater by arsenic in bangladesh: a public health emergency. Bulletin of the World Health Organization 2000; 78:1093-103.

[29] Zhao FJ, Adams ML, Dumont C, et al. Factors affecting the concentrations of lead in british wheat and barley grain. Environ Poll 2004; 131: 461-8.

[30] Ahmad J, Goldar B, Smita M. Value of arsenic-free drinking water to rural households in Bangladesh. J Environ Manag 2005; 74: 173 85.

[31] Sheppard SC. Summary of phytotoxic levels of soil arsenic. Water Air Soil Poll 1992; 64: 539-50.

[32] Jiang QQ, Singh B.R. Effect of different forms and sources of arsenic crop yield and arsenic concentration. Water Air Soil Poll 1994; 74: 321-43.

[33] Matschullat J. Arsenic in the geosphere - a review. Sci Total Environ 2000; 249: 297-312.

[34] Geng CN, Zhu YG, Tong YP, Smith SE, Smith FA. Arsenate (As) uptake by and distribution in two cultivars of winter wheat (triticum aestivum l.). Chemosphere 2006; 62: 608-15.

[35] Elfving DC, Haschek WM, Stehn RA, Bache CA, Lisk DJ. Heavy metal residues in plants cultivated on and in small mammals indigenous to old orchard soils. Arch Environ Health 1978; 33: 959.

[36] Jedynak L, Kowalska J, Kossykowska M, Golimowski J. Studies on the uptake of different arsenic forms and the influence of sample pretreatment on arsenic speciation in the white mustard (Sanapis alba). Microchem J 2010; 94: 125-9.

[37] Gee GW, Bauder JW. Particle-size analysis, p. 383-411, In A. Klute, (ed.) Methods of soil analysis, part 1. $2^{\text {nd }}$ ed. American Society of Agronomy; Madison, WI, 1986.

[38] McGrath SP, Cunliffe CH. A simplified method for the extraction of the metals $\mathrm{Fe}, \mathrm{Zn}, \mathrm{Cu}, \mathrm{Ni}, \mathrm{Cd}, \mathrm{Pb}, \mathrm{Cr}, \mathrm{Co}$ and $\mathrm{Mn}$ from soils and sewage sludges. J Sci Food Agric 1985; 36: 794-8.

[39] Anderson KA, Isaacs B. Simultaneous determination of arsenic, selenium, and antimony in environmental samples by hydride generation for inductively coupled plasma atomic emission spectrometry. J AOAC Int 1995; 78: 1055-60.

[40] Mehlich A. Mehlich III soil test extractant: a modification of Mehlich II extracant. Commun Soil Sci Plant Anal 1984; 15: 140916.

[41] SAS. SAS, proc mixed, 12.1 User's Guide, Cary, NC: SAS Institute Inc 2012; p. 9030.

[42] Dudka S, Miller WP. Permissible concentrations of arsenic and lead in soils based on risk assessment. Water Air Soil Pollut 1999; 113: 127-32.

[43] Michalska M, and Asp H. Influence of lead and cadmium on growth, hevy metal uptake, and nutrient concentrationof three lettuce cultivars grown in hydroponic culture. Commun. Soil Sci Plant Anal 2001; 32: 571-83.

[44] Bunzl K, Trautmannsheimer M, Schramel P, Reifenhauser W Availability of arsenic, copper, lead, thallium and various vegetables grownin slag-contaminated soils. J Environ Qual 2001; 30: 934-9.

[45] Codling EE. Long-term effects of lime, phosphorus, and iron amendments on water extractable arsenic, lead and bioaccessible lead from contaminated orchard soils. Soil Sci 2007; 172: 811-9.

Received: April 12, 2014

Revised: June 03, 2014

Accepted: June 04, 2014

(C) E. E. Codling; Licensee Bentham Open .

This is an open access article licensed under the terms of the Creative Commons Attribution Non-Commercial License (http://creativecommons.org/licenses/by-nc/3.0/) which permits unrestricted, non-commercial use, distribution and reproduction in any medium, provided the work is properly cited. 